\title{
Meaningful Learning in the Teaching of Culture: The Project Based Learning Approach
}

\author{
Ang Chooi Kean \& Ngu Moi Kwe \\ International Languages Department, Institute of Teacher Education International Languages Campus, Kuala Lumpur, \\ Malaysia \\ Correspondence: Ang Chooi Kean, International Languages Department, Institute of Teacher Education International \\ Languages Campus, Lembah Pantai, 59200 Kuala Lumpur, Malaysia.
}

Received: November 6, 2013 Accepted: November 20, 2013 Online Published: March 1, 2014

doi:10.11114/jets.v2i2.270

URL: http://dx.doi.org/10.11114/jets.v2i2.270

\begin{abstract}
This paper reports on a collaborative effort taken by a team of three teacher educators in using the Project Based Learning (PBL) approach in the teaching of Japanese culture with the aim to investigate the presence of actual "meaningful learning" among 15 students of a 12-Week Preparatory Japanese Language course under a teacher training programme. The instrument used in the study was a blog created for the project and the data collected was a compilation of students' reflection reports and messages about their learning experience uploaded onto the blog. The qualitative data was analysed using an adapted version of Jonassen's 1999 rubric on meaningful learning attributes. Findings from this study showed a significant presence of meaningful learning attributes, namely constructive and authentic learning. This paper reaffirms project-based instruction as a viable and flexible alternative to traditional intensive coursework.
\end{abstract}

Keywords: meaningful learning, project based learning, teaching of Japanese culture, teacher training programme

\section{Introduction}

Culture is a vital component of language learning. "Learning language is essentially a socially oriented process...(it) is also linked with the wider cultural and cognitive processes" (Foley \& Thompson, 2003, p.62). Students cannot truly master a language until they have also mastered the cultural contexts in which the language occurs (National Standards in Foreign Language Education Project, 1996, cited in Peterson \& Coltrane, 2003, p. 1). It means knowing what is appropriate to say to whom, and in what situations, and it means understanding the beliefs and values represented by the various forms and usages of the language. Hence, to bridge the cultural gap, second language teachers should identify and incorporate key cultural items as well as activities into lesson plans to enrich and inform the teaching content so that students can function effectively not only in the particular language but also in that society.

In this regard, non-native teachers of foreign languages (especially those who were trained outside the target language countries) need assistance in overcoming their shortcomings in the lack of knowledge about the target language culture. One way to overcome this problem is for foreign language teachers to firstly, identify key cultural items in every aspect of the language that they teach. Next, they could present the cultural items at a level or manner in which the students can attach some relationship between the information and their own background experiences. Following that they could actively test whether students are attaining the set cultural goals.

This paper reports on an instructional package of teaching Japanese culture via the project-based learning (PBL) approach employed in a 12-Week Preparatory Japanese Language Course under a teacher training programme. The instructor believed that PBL provides added advantages in the learning of a foreign culture with its "rich space" in which students can collaborate and develop intercultural skills as well as an understanding of their discipline in the target culture while harnessing the potential of Web 2.0 technologies and applying the principles of project-based learning. In addition, the instructional package also attempts to generate a relationship between the cultural information of the target language with the students' own background experiences in terms of relating the cultural practice as a solution to an existing global or universal problem. In other words, in order to promote meaningful learning of a foreign culture beyond the boundary of the target language country, the teaching of culture and its related awareness are not limited or restricted to the target language but instead extended to a more globalized view of the specific practice of the culture. In addition, the instructional content also includes a systematic evaluation of the students' learning products. 


\section{Review of Related Literature}

\subsection{Purposes of Teaching Culture}

Traditionally, the emphasis in teaching culture in the language classroom has been on the acquisition of cultural knowledge and, more recently, on developing cultural awareness. These two constitute an important aspect of the intercultural competence. Tomlinson and Masuhara (2004, p.6) characterised the nature of cultural awareness as (1) perceptions of one's own and other people's cultures, i.e. they develop in the mind; (2) dynamic, i.e. they are constantly being added and changed; (3) variable, i.e. modified from experience; (4) multi-dimensional, i.e. represented through sensory images and mental pictures; and, lastly, (5) they are interactive, i.e. they are interrelated and influence each other. Tomlinson and Masuhara (2004) also claimed that while cultural knowledge is mostly gained from other people, cultural awareness is gained from personal experience either directly through visits to foreign countries or indirectly through music, films and literature. According to Byram (2000, p.9), intercultural competence involves five elements: (1) attitudes: curiosity and openness, suspending disbelief about one's own and other cultures, (2) knowledge: products and practices of one's own and the other culture, societal and individual interaction, (3) skills in interpreting and relating: interpreting documents or events from the other culture and relating them to the documents from one's own culture, (4) skills of discovery and interaction: ability to acquire new knowledge and operate knowledge, skills and attitudes in real-time communication and (5) critical cultural awareness/political education: ability to evaluate critically practices and products of one's own and the other culture. In contrast, Seelye (1993, p.30) suggested six instructional goals, which he summarised as follows: teachers should "help the students to develop interest in who in the target culture did what, where, when and why" (the first five goals) and "some sophistication in evaluating statements about the culture and finding out more about it" (the sixth goal). Tomalin and Stempleski (1993, p.7-8) modified Seelye's cultural instruction goals into the following aspects: Helping students to

develop an understanding of the fact that all people exhibit culturally-conditioned behaviours;

develop an understanding that social variables such as age, sex, social class, and place of residence influence the way in which people speak and behave;

- become more aware of conventional behaviour in common situations in the target culture;

- increase their awareness of the cultural connotations of words and phrases in the target language;

- develop the ability to evaluate and refine generalisations about the target culture, in terms of supporting evidence;

. develop the necessary skills to locate and organise information about the target culture;

stimulate their intellectual curiosity about the target culture, and encourage empathy towards its people.

Stern (1992), who studied goals of teaching culture set by several other scholars concluded that all goals, despite the differences in terminology, stressed on the cognitive aspect, that is: "knowledge about the target culture, awareness of its characteristics and differences between the target culture and the learner's own culture." A "research-minded outlook" (willingness to find out, to analyse, synthesize and generalize) is also important (p.212-215).

In the context of this study, the purposes of teaching culture comprise both the traditional (acquiring cultural knowledge) and contemporary (developing cultural awareness) emphases discussed above. Specifically, it aims at developing the students' understanding and appreciation of Japanese culture and in enhancing their cross-cultural awareness via the project-based learning approach. In this study, the cultural area of festival practice, Bon odori (Bon dance) was chosen in line with the targeted learning outcome in the course curriculum, namely to observe and identify the underlying values and aspects of Japanese culture as practised traditionally, contemporarily and internationally.

\subsection{The Project-based Learning (PBL) Approach}

Project-based learning (PBL) according to Thomas (2000), is a model that organizes learning around projects. Project-based learning involves completing complex tasks that typically result in a realistic product, event, or presentation to an audience. The dynamic approach to teaching in project-based learning (PBL) provides an all-round enriching education where students are inspired to explore, investigate, consider alternatives, understand their world and apply what they learn to real-life experiences. The need to construct and organize knowledge and to communicate effectively to audiences will have a positive impact on their learning. Thomas (2000) identified five key components of effective project-based learning: (1) It is central to the curriculum, (2) It is organized around driving questions that lead students to encounter central concepts or principles, (3) It is focused on a constructive investigation that involves inquiry and knowledge building, (4) It is student-driven (students are responsible for designing and managing their work), and (5) It is authentic, focusing on problems that occur in the real world which people care about (p. 3-4).

The dynamic approach to teaching in project-based learning (PBL) provides an all-round enriching education where students are inspired to explore, investigate, consider alternatives, understand their world and apply what they learn to 
real-life experiences. The need to construct and organize knowledge and to communicate effectively to audiences will have a positive impact on their learning.

Figure 1 that follows displays an overview of the teaching strategy and its stages involved in a PBL instruction. Through such teaching strategy, project-based learning shifts away from teacher-directed learning to more learner-centered learning activities that focus on real world issues and practices. Characteristics of PBL are built on inquiry strategies that foster natural curiosity of real issues and concerns affecting the lives of the pupil and focus on developing skills that enable pupils to rely on strategies to resolve complex problems encountered by daily living.

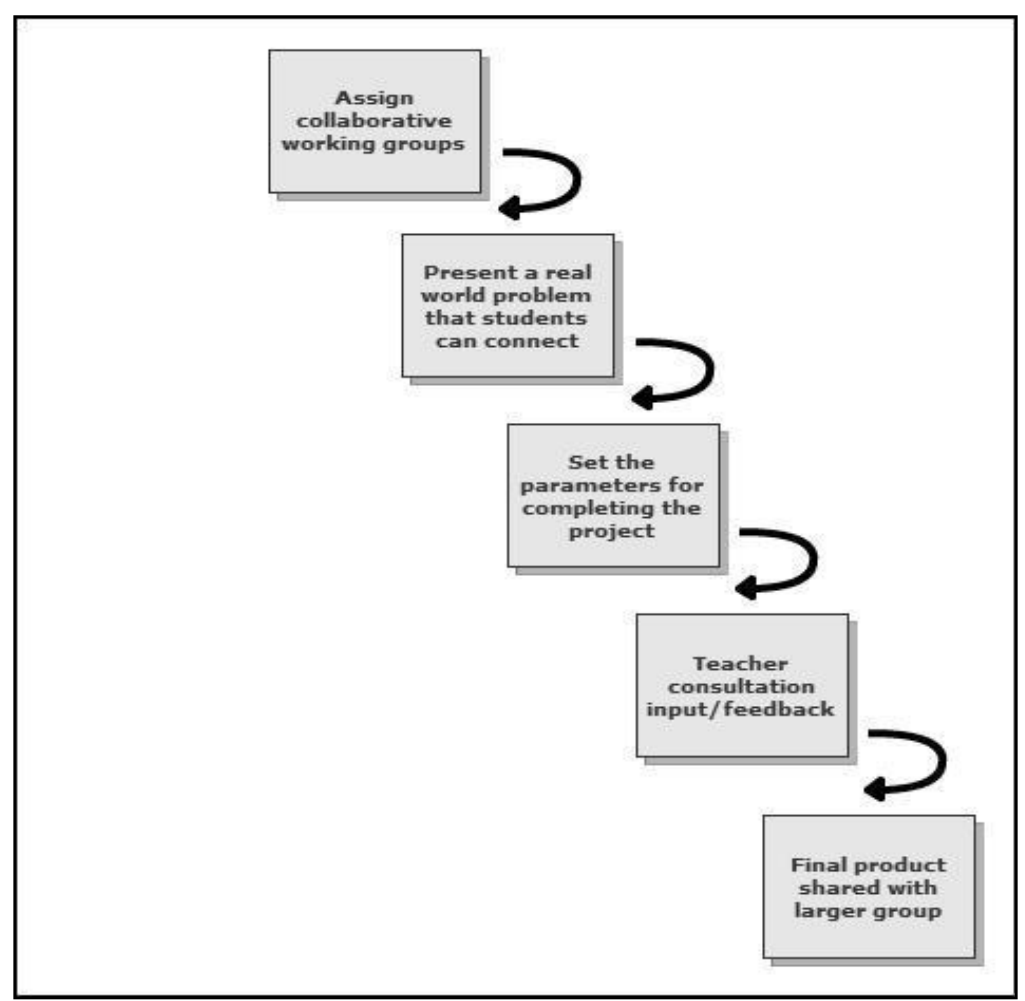

Adapted from: http://www.worksheetlibrary.com/teachingtips/projectbased.html

Figure 1. Project-based Learning Visual Concept Diagram

\subsection{Why the Project-based Learning (PBL) Approach?}

Adopting a project-based teaching approach in the classroom can energize the curriculum. Research has shown that PBL is a viable and flexible alternative to traditional short-term intensive language programme (see Foss, Carney, McDonald \& Rooks, 2007). It enables teachers to bridge academic instruction with real-life experience in communicating across cultures. PBL helps students to develop their skills holistically while improving their ability to work in groups and managing their time well. As students are evaluated on the basis of their projects, rather than on the comparatively narrow rubrics defined by exams, essays, and written reports, assessment of project-based work is often more meaningful to them. Students also thrive on the greater flexibility of project learning. In addition to participating in traditional assessment, they might be evaluated on presentations to a community audience they have assiduously prepared for, informative tours of a local historical site based on their recently acquired expertise, or screening of a scripted film they have painstakingly produced.

Furthermore, PBL is also an effective way to integrate technology into the curriculum. A typical project can easily accommodate computers and the Internet, as well as interactive whiteboards, global-positioning-system (GPS) devices, digital still cameras, video cameras, and associated editing equipment. Blumenfeld et al. (1991) advocate the ways that technology can support students and teachers as they work on projects, so that motivation and thoughts are sustained.

\subsection{Meaningful Learning via PBL}

The active and engaged learning plus the real-world relevance of PBL enables students to obtain a deeper knowledge of the subjects under study as well as enables them to hone their organizational and research skills, develop better 
communication with their peers and adults as well as develop confidence and self-direction as they move through both team-based and independent work. In short, a well-designed and well-implemented project can be the ideal platform for generating meaningful learning because all the relevant skills and knowledge obtained can be utilised in their daily lives.

According to Larmer and Mergendoller (2010), a project is meaningful if it fulfils two criteria. First, students must perceive the work as personally meaningful, as a task that matters and that they want to do well. Second, a meaningful project fulfils an educational purpose. For a project to be meaningful to students, they suggest that seven essentials needed to be fulfilled.

(1) A Need to Know: "With a compelling student project, the reason for learning relevant material becomes clear: I need to know this to meet the challenge I've accepted."

(2) A Driving Question: A good driving question gives students a sense of purpose and challenge (In the study context, the question is: "How can we help to narrow the generation gap?")

(3) Student Voice and Choice: In terms of making a project feel meaningful to students, the more voice and choice, the better (Students can decide what products they will create, what resources they will use, what tasks they would do, how they would work together, how they will structure their time and so on.)

(4) 21st Century Skills: A project should give students opportunities to build 21st century skills such as collaboration, communication, critical thinking, and the use of technology which will serve them well in the workplace and life.

(5) Inquiry and Innovation: Students find project work more meaningful if they conduct real inquiry. Exposure to a variety of authentic and challenging real-life tasks, will make them learn to innovate- find a new answer to a driving question, a new product, or an individually generated solution to a problem

(6) Feedback and Revision: When students refer to rubrics and other sets of criteria to critique their own as well as one another's work. Self-evaluation and reflections as well as feedback from peers make learning more meaningful.

(7) A Publicly Presented Product: When students present their work to a real audience, they will try to replicate the kinds of tasks done by professionals and in the process, create authentic products that people outside school might use (p.1-2)

\subsection{Meaningful Learning and the Use of Technology}

The concept of meaningful learning was advocated by Ausubel who suggested that meaningful learning occurs when new experiences are related to what a learner already knows. (Grabe \& Grabe, 2000). In a further development, Jonassen and his colleagues (Jonassen, et al., 2003) applied a constructivist perspective to the use of technology in schools to create technology-based activities that would support meaningful learning. They defined meaningful learning as occurring when students were actively engaged in making meaning, and broke down this definition into five "interrelated, interactive, and interdependent attributes" with the most meaningful learning activities supporting combinations of these attributes. The five attributes were Active (manipulative, observant), Constructive (articulative, reflective), Intentional (reflective, regulatory), Authentic (complex, contextualised) and Cooperative (collaborative, conversational, p.2-3). Jonassen et al.(2003), proposed a shift in the way educators conceive of technology use in education, suggesting that they "begin to think about technologies as learning tools that students learn with not from" and this perspective matches the ways in which technology is likely to be deployed by informal learners who are unconstrained by externally imposed formal learning structures. Therefore, Jonassen et al's attributes of meaningful learning were used to evaluate the learning that took place among the students in their blog.

\section{The PBL Cultural Package: "Mind the Generation Gap: The Japanese Way"}

The project in this study was based on the PBL concept as illustrated in the Figure 1 above. It involved 15 students of a 12-Week Preparatory Japanese Language Course under a teacher training programme. The goal of this project was to bridge the generation gap through time spent together in play and fun as in folk dancing. In this project, the students put up an odori (dance) workshop to teach Kawachi Ondo a popular Japanese Folk Dance during the "5th Japanese Language Festival" organized by the Japanese Language Society of Malaysia (JLSM).

The students worked in groups to gather relevant materials from the internet and then created a brochure about the dance to promote Kawachi Ondo, as a way of bridging the generation gap between the young and the old. They then assumed the role of dance instructors and taught the dance steps to visitors of this cultural event. They also interviewed members of the public to find out their views on using folk dancing as a way of bridging the generation gap. A blog was set up for the Kawachi Ondo dance enthusiasts to share their views and to post the interview findings.

The second platform was the The International Languages Week of IPG KBA. For this event, the students prepared a multimedia PowerPoint to showcase Kawachi Ondo and to raise awareness of its benefits in bridging the generation gap. 
Finally, the students posted reflections of their learning on the Kawachi Ondo blog. Evaluation of the students' work was done using three rubrics: brochure, blog and the multimedia presentation.

\section{Research Objective}

As an innovative attempt to promote meaningful learning of a foreign culture using technology, the PBL based instructional package developed under this study attempts to generate a relationship between the information of the target culture with the students' own background experiences in terms of relating the cultural practice as a solution to an existing global or universal problem. This exploratory study aimed to investigate the presence of actual "meaningful learning" among the students in the approach. However, due to the extensiveness of the project with its numerous learning products, the scope of the examination in this report was narrowed down and restricted only to the blog created under the project.

\section{Methodology}

This exploratory study involved 15 students of a 12-Week Preparatory Japanese Language Course under a teacher training programme. The instrument used in the study was the blog created for this project. The data was the students' reflection reports and messages about their learning experiences which were uploaded onto the blog. The qualitative data was analysed using a rubric adapted by Mohamed Amin and Amelia (2009) from Jonassen's 1999 rubric based on four meaning learning attributes (see Table 1).

The adapted version of the rubric was employed in this study as the four attributes of meaningful learning (i.e. intentional learning, constructive learning, active learning and authentic learning) corresponded with the requirement of the study. However, the attribute of collaborative learning was excluded because it is an obvious attribute under the PBL approach.

Table 1. Adapted Rubric for Identifying the Attributes of Meaningful Learning

\begin{tabular}{|c|c|c|c|c|c|}
\hline Attributes & Indicators & $\begin{array}{c}3 \\
\text { (10 statements \& } \\
\text { remarks \& above) }\end{array}$ & $\begin{array}{c}2 \\
\text { (6-9 statements } \\
\text { \& remarks) }\end{array}$ & $\begin{array}{c}1 \\
(1-5 \text { statements } \\
\& \text { remarks })\end{array}$ & $\begin{array}{c}0 \\
\text { (No statement } \\
\text { \& remark) }\end{array}$ \\
\hline $\begin{array}{l}\text { Intentional } \\
\text { Learning }\end{array}$ & $\begin{array}{l}\text { 1. Learning goals are predetermined by } \\
\text { the students. } \\
\text { 2. Students use alternative means such } \\
\text { as timelines, graphs, mind maps and } \\
\text { concept maps in the construction of } \\
\text { knowledge. }\end{array}$ & & & & \\
\hline $\begin{array}{l}\text { Constructive } \\
\text { Learning }\end{array}$ & $\begin{array}{l}\text { 1. Students are constantly reflecting on the } \\
\text { learning process. } \\
\text { 2. Students are able to assess, evaluate and } \\
\text { criticise their peers' ideas critically and } \\
\text { constructively. } \\
\text { 3. Students are able to respond to the } \\
\text { instructor's questions. }\end{array}$ & & & & \\
\hline $\begin{array}{c}\text { Active } \\
\text { Learning }\end{array}$ & $\begin{array}{l}\text { 1. Students are able to initiate discussions } \\
\text { from the instructor. } \\
\text { 2. Students are constantly collaborating and } \\
\text { discussing their learning tasks and ways to } \\
\text { handle those tasks. } \\
\text { 3. Students are the primary information and } \\
\text { knowledge disseminators. }\end{array}$ & & & & \\
\hline $\begin{array}{l}\text { Authentic } \\
\text { Learning }\end{array}$ & $\begin{array}{l}\text { 1. Students are able to relate their learning } \\
\text { process with their experience and their } \\
\text { environment. } \\
\text { 2. Students construct new ideas through the } \\
\text { learning process. } \\
\text { 3. Students are able to apply their new } \\
\text { knowledge to real-life situations. }\end{array}$ & & & & \\
\hline
\end{tabular}




\section{Findings and Discussion}

In this study, we analysed the students' reflection which included reports and messages about their learning experiences to determine the presence of the four attributes mentioned above. Each indicator was given a score based on the frequencies of statements and remarks identified through the content analysis of the reflection reports and messages. Results of the data analysis are as shown in Table 2.

Table 2. Data Analysis based on the Adapted Rubric for Identifying the Attributes of Meaningful Learning

\begin{tabular}{|c|c|c|c|c|c|}
\hline Attributes & Indicators & $\begin{array}{c}3 \\
(10 \\
\text { statements \& } \\
\text { remarks \& } \\
\text { above) }\end{array}$ & $\begin{array}{c}2 \\
(6-9 \\
\text { statements \& } \\
\text { remarks) }\end{array}$ & $\begin{array}{c}1 \\
(1-5 \\
\text { statements \& } \\
\text { remarks })\end{array}$ & $\begin{array}{c}0 \\
(\text { No } \\
\text { statement \& } \\
\text { remark) }\end{array}$ \\
\hline $\begin{array}{l}\text { Intentional } \\
\text { Learning }\end{array}$ & $\begin{array}{l}\text { 1. Learning goals are predetermined } \\
\text { by the students. } \\
\text { 2. Students use alternative means } \\
\text { such as timelines, graphs, mind } \\
\text { maps and concept maps in the } \\
\text { construction of knowledge. }\end{array}$ & & & $\checkmark$ & $\nu$ \\
\hline Total score & $1 / 6$ & & & & \\
\hline Percentage & $1.67 \%$ & & & & \\
\hline $\begin{array}{l}\text { Constructive } \\
\text { Learning }\end{array}$ & $\begin{array}{l}\text { 1. Students are constantly reflecting } \\
\text { on the learning process. } \\
\text { 2. Students are able to assess, } \\
\text { evaluate and criticise their peers' } \\
\text { ideas critically and constructively. } \\
\text { 3. Students are able to respond to the } \\
\text { instructor's questions. }\end{array}$ & 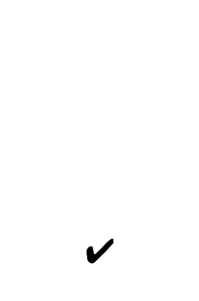 & $\nu$ & $\nu$ & \\
\hline $\begin{array}{l}\text { Total score } \\
\text { Percentage }\end{array}$ & $\begin{array}{c}6 / 9 \\
66.7 \%\end{array}$ & & & & \\
\hline $\begin{array}{l}\text { Active } \\
\text { Learning }\end{array}$ & $\begin{array}{l}\text { 1. Students are able to initiate } \\
\text { discussions from the instructor. } \\
\text { 2. Students are constantly } \\
\text { collaborating and discussing their } \\
\text { learning tasks and ways to handle } \\
\text { those tasks. } \\
\text { 3. Students are the primary } \\
\text { information and knowledge } \\
\text { disseminators. }\end{array}$ & & & $\nu$ & $\boldsymbol{V}$ \\
\hline $\begin{array}{l}\text { Total score } \\
\text { Percentage }\end{array}$ & $\begin{array}{c}2 / 9 \\
22.2 \%\end{array}$ & & & & \\
\hline $\begin{array}{l}\text { Authentic } \\
\text { Learning }\end{array}$ & $\begin{array}{l}\text { 1. Students are able to relate their } \\
\text { learning process with their } \\
\text { experience and their environment. } \\
\text { 2. Students construct new ideas } \\
\text { through the learning process. } \\
\text { 3. Students are able to apply their new } \\
\text { knowledge to real-life situations. } \\
5 / 9\end{array}$ & & $\nu$ & $\checkmark$ & \\
\hline $\begin{array}{l}\text { Total score } \\
\text { Percentage }\end{array}$ & $55.6 \%$ & & & & \\
\hline
\end{tabular}




\title{
6.1 Intentional Learning
}

As illustrated in Table 2, from the data analysis based on the rubric, we found that none of the attributes were without any score. The findings indicated the presence of all the four attributes. However, the percentage scores varied from the lowest score of $1.67 \%$ to the highest score of $66.7 \%$. The lowest score was the attribute of intentional learning, where no evidence was found on the students predetermining the learning goals. The findings were as expected as the goals and learning outcomes in the instructional package under the study were determined through the learning tasks. However, there were two evidences which indicated that students did use alternative means in achieving the determined learning goals. Nevertheless, there were no specific examples of mind maps and graphs or timelines being used by the students. It could be presumed that because the platform for posting their reflection reports and messages or comments was a blog, it was easier and less time consuming to use texts rather than other means.

\subsection{Constructive Learning}

The findings indicated the highest percentage of $66.7 \%$ for constructive learning. All the students were able to respond to the content questions given by the instructor (Indicator 3).

Through the content analysis of the data collected, the researchers found 9 statements and messages in the category of assessing and evaluating their peers' ideas critically and constructively (Indicator 2). An example of a message is as follows:

\begin{abstract}
"It is a very interesting personal opinion. I do agree that odori encourages interaction. Not all folk dances or line dancing give the opportunity to interact while dancing $n$ surprisingly, this one does! And sometimes, like you, you will think elders do not understand you when they think they do. Same goes to the elders. They will think you do not know what you are doing when you feel so sure about what you do. In fact, even people of the same generation or age will not understand each other. This is because we are individuals, unique in our own ways. No one can know exactly what we are thinking. So this blog is not really pinpointing who is right or wrong, who does not understand whom. It is about interaction and so does odori. With a platform to interact, we will live a better world....".
\end{abstract}

As for indicator 1, it is rather interesting that we found less than 5 statements and messages in that category. This is presumably due to several factors:

- Most of the students were more concerned with responding to the content questions posted by the instructor in their report rather than reflecting on their learning process.

- The instructional package consisted of various learning components in different stages that were linked and built up to the last stage of production (i.e. the dance workshop). This might have caused the students to be focusing more on the workshop rather than on their learning process in the earlier stages.

- The students should have been required to reflect periodically according to the various learning components in different stages.

In a constructive learning environment, the students should be able to identify their own strengths and weaknesses through the constructive reflections that they make periodically (Mohamed Amin and Amelia, 2009). Nevertheless, as noted by Mohamed Amin and Amelia (2009, p.136), "a constructive learning environment is present even though not everyone in the community engages in reflection".

\subsection{Active Learning}

The analysis indicated a low percentage score of $22.2 \%$ for the active learning attribute. Even though there were evidences for both Indicator (1) and Indicator (3), there were neither evidence of statements nor messages for Indicator (2). This might be due to the fact that constant collaboration and discussion among the students about their learning tasks and ways to handle those tasks at this final stage was not necessary. With regards to the limited number of statements and messages of initiating discussions without probing from instructors (Indicator 1), a possible reason could be that the content questions posted by the instructor could have nullified the necessity for this role of the students or taken up the "space" for this category. Similarly, the minimal number of statements and messages about the role of primary information disseminators (Indicator 3) could be because the scope of discussions was concentrated on the content questions posted by the instructor which impeded the extensiveness of the students' thinking and search for other related information.

\subsection{Authentic Learning}

This attribute recorded a percentage score of 55.6\% with evidences for all the three indicators. Authentic learning occured when the students were able to apply the knowledge or insights they had obtained to their daily lives or real situations. We found such evidence in the statements and messages recorded: 
"I was not very comfortable teaching dances to others but after this experience, it shows me how dance can help me to bring my future students closer, filling up the gap that may exist between us. Furthermore, I also think that it is a very good exercise. At the end of the day, Ifelt so tired and I slept well that night. Odori is very simple yet it allows us to exercise."

The students felt that the learning process they went through were very meaningful because the knowledge and experience they gained could be implemented in their teaching and learning in schools. Another indication of authentic learning was the real application of the things these individuals learnt to their school environment as Japanese language teachers. However, this could only be verified through field observations after the students had been posted to their respective schools. Nevertheless, through the analysis of the recorded statements and messages, we assumed that the students would indeed implement what they had learnt. An example of such a record is as follows:

\section{"I would really love to incorporate this dance in the syllabus once I'm teaching at school. The kawachi ondo is a great introduction into the esoteric world of traditional dance."}

\section{Implications}

Overall, the findings indicated that all four attributes of meaningful learning were present in the study, although they occurred in varying degrees. This implied that through PBL, supported by a variety of technological integration, teaching of culture could be implemented in a meaningful learning environment where students explore and seek knowledge according to their needs and interests without having to depend on the instructor to provide them that knowledge. As Anderson, Rourke, Archer and Garrison (2000, as cited in Mohamed Amin \& Amelia, 2009) suggested that there are cognitive, social and teaching forms of "presence" that should exist in a meaningful learning environment. Cognitive presence refers to how far the students are able to form their comprehension and knowledge through active interaction and communication in their learning process. In addition, the cognitive presence can help to create a challenging learning environment that can force students to optimise their cognitive potential in handling learning tasks and solving learning problems. The findings in this study illustrated that the students have indeed optimized their cognitive potential in carrying out the project, especially in handling their tasks as the dance instructors. Social presence refers to the way students express themselves in social and emotional contexts. In this study, there was a clear indication that social presence had indeed supported a conducive, collaborative learning environment wherein the students felt comfortable participating actively in the project.

The findings also implied that project-based instruction is a more viable and effective alternative instruction to teaching culture not only to the students but also to their foreign language teachers. As the subjects of this study are going to be Japanese language teachers upon completion of the training programme, this particular cultural learning experience will probably influence them later as teachers in their teaching of culture. This view is supported by Mahoney (2009) who in her case study of the teaching culture of two non-native speaking teachers; found that the teachers' own attitudes, beliefs and past experiences have an influence in their teaching.

As asserted by Mohamed Amin and Amelia (2009), the importance of the instructor in creating a meaningful learning environment cannot be denied. Important tasks for the instructor in a meaningful learning environment are planning and organizing tasks, motivating and offering support to students and making sure the environment is conducive to and suitable for meaningful learning. However, the findings on the limited presence of active learning in contrast to the high degree of presence of constructive learning (namely in responding to instructor's questions) implied that in planning the project-based learning tasks, the instructor might have hindered "active learning" by posting the content questions in order to guide the learning towards the "right" direction in terms of the learning goals. In short, it would have been much more meaningful if the instructor did not attempt to "control", "direct" or "guide" the learning too much.

\section{Conclusion}

It was mentioned in the beginning that this is an exploratory study. As a result, it cannot be denied that there are some gaps that can be filled with further and deeper research. For future research, it would be worthwhile to study the presence of meaningful learning or other learning impacts in other student products besides the blog. Another interesting area of study would be the assessment of the learning processes and products.

As noted by Saluveer (2004), despite the recognition of the importance of culture in language classes, the teaching of it has still remained rather limited. The main reasons for that are the lack of time, the issues of designing a cultural syllabus and choosing appropriate techniques and, lastly, the presentation of culture-related topics and activities in teaching materials. The instructional package in this study was indeed an attempt to overcome these issues, through collaborative efforts of three instructors in designing and providing cultural learning experiences with technology using PBL.

\section{Acknowledgements}

The authors would like to express their appreciation to Ms Ooi Say Tin for her invaluable advice in PBL and also in 
editing the paper. A note of gratitude is also extended to the students as the subjects of the research project.

\section{References}

Barron, B., \& Darling-Hammond, L. (2008). Teaching for meaningful learning: A review of research on inquiry-based and cooperative learning. In L. Darling-Hammond, Brigid Barron, et al. (2008). Powerful Learning: What We Know About Teaching for Understanding. San Francisco: Jossey-Bass. Retrieved on March 14, 2012 from http://www.edutopia.org/pdfs/edutopia-teaching-for-meaningful-learning.pdf

Blumenfeld, P. C., Soloway, E., Marx, R. W., Krajcik, J. S., Guzdial, M., \& Palincsar, A. (1991). Motivating project-based learning: Sustaining the doing, supporting the learning. Educational Psychologist, 26(3/4), 369-398. http://dx.doi.org/10.1080/00461520.1991.9653139

Byram, M. (2000). Assessing intercultural competence in language teaching. Sprogforum, 6(18), 8-13.

Foley, J., \& L. Thompson. (2003). Language Learning. London: Arnold

Grice, H.P. (1975) Logic and conversation, in Cole, P., \& J.L.Morgan (eds.): Speech Acts, Syntax and Semantics 3. New York: Academic Press, 41-58.

Foss, P., Carney, N., McDonald, K., \& Rooks, M. (2007). Project-based learning activities for short-term intensive English programs. Asian EFL Journal, 23, October 2007.

Grabe, M., \& Grabe, C. (2000). Integrating the Internet for Meaningful Learning. Boston: Houghton Mifflin Co.

Hidasi, J. (2006). The Impact of Culture on Second Language Acquisition. Retrieved on January 15, 2013 from http://www.childresearch.net/RESOURCE/RESEARCH/2006/exfile/HIDASI.pdf

Jonassen, D. H., Howland, J. L., Moore, J. L. and Marra, R. M. (2003). Learning to Solve Problems with Technology: A Constructivist Perspective. New Jersey: Merrill Prentice Hall.

Jonassen, D. H., \& Strobel, J. (2006). Modeling for meaningful learning. In Engaged learning with emerging technologies (pp. 1-27). Springer Netherlands. http://dx.doi.org/10.1007/1-4020-3669-8_1

Larmer, J., Mergendoller, J. R. (2010). Seven essentials for project-based learning. Educational Leadership. Retrieved on March 13, 2012 from http://www.ascd.org/publications/educational_leadership/sept10/ vol68/num01/Seven_Essentials_for_Project-Based_Learning.aspx

Mahoney, C. (2009). Teaching culture in the Japanese language classroom: A NSW case study. New Voices, 3, 104-125.

Mohamed Amin Embi \& Amelia Abdullah. (2009). Meaning learning in a networked learning environment. In Mohamed Amin Embi (ed). (2009). Computer-Mediated Communication: Pedagogical Implications of Malaysian Research Findings. Shah Alam: Karisma Publications.128-141.

Peterson, E., \& Coltrane, B. (2003). Culture in Second Language Teaching. Retrieved on March 20, 2012 from http://www.cal.org/resources/digest/0309peterson.html

Thomas, J.W. (2000). A review of research on project-based learning. Retrieved on November 26, 2013 from http://www.bobpearlman.org/BestPractices/PBL_Research.pdf

Tomalin, B., \& Stempleski, S. (1993). Cultural Awareness. Oxford: Oxford University Press.

Tomlinson, B. and Masuhara, H. (2004). Developing cultural awareness. Modern English Teacher, 13(1), 5-11.

Saluveer, E. (2004). Teaching Culture in English Classes: Master's Thesis. Retrieved on March 20, 2012 from http://www.lara25.com/mywebdisk/CI-EP/Saluveer.pdf

Seelye, H. N. (1993). Teaching culture: Strategies for inter- cultural communication. (3rd ed.) Lincolnwood, IL: National Textbook Company.

Stern, H. H. (1992). Issues and Options in Language Teaching. Oxford: Oxford University Press.

\section{$(\mathrm{cc}) \mathrm{EY}$}

This work is licensed under a Creative Commons Attribution 3.0 License. 